\title{
НЕКОЛИКО СЛУЧАЈЕВА СИНТАКСИЧКЕ СИНОНИМИЈЕ НА ПОДРУЧЈУ ДОПУНСКИХ РЕЧЕНИЦА
}

Под термином „допунска реченица” у овом ћемо раду разумети зависну реченицу која може служити као једна од допуна у односу на глагол, придев, именицу или предлог, као у примерима:

1) Организаторима овог скупа захваљујем што су ми омогућили учешће.

2) Сигуран сам да ће се скуп показати корисним.

3) Желео бих изразити своју радост што вас овде видим.

(На питање о томе како реченица може бити допуна предлогу враћамо се ниже.) То су дакле већином изричне реченице и експликативне реченице које познајемо из школске граматике, само што смо овде дали предност термину „допунска реченица” како бисмо нагласили да таква реченица врши службу једног од делова неке друге (главне) реченице, нпр. службу ближег или даљег објекта.

Појам допуне се у лингвистици различито дефинише. Ту ћемо се определити за шире схватање допуне, па узимамо да у допуне спадају и субјекти. Према томе, допунска реченица може бити и таква зависна реченица која врши службу субјекта глагола или субјекта у другој врсти предикације. Нпр.:

4) Увек ме радује да дођем овамо.

5) Корисно је да се слависти повремено састају.

6) Велика је заслуга Међународног славистичког центра што се Научни састанак тако лепо организује.

Проширили бисмо појам допунске реченице још на један начин, па ћемо ту укључити и допунски инфинитив. Инфинитив се додуше на синтаксичкој површини не понаша сасвим као реченица. У српскохрватском језику инфинитивна конструкција може садржавати један или више објеката, али нема никад својег субјекта, за разлику од обичне ре- 
ченице. Међутим, инфинитив можемо добро описати као кондензовану реченицу, односно, ако хоћемо да се послужимо терминологијом генеративне граматике, то је трансформ једне реченице, а на нивоу дубинске синтаксичке структуре има све одлике које реченица обично има. Инфинитив се јавља у истим синтаксичким службама као допунска реченица, па ћемо их зато заједно и разматрати. Он може бити допуна (у ужем смислу) глаголу, као кад се каже:

7) Желимо добро искористити време.

Понекад је и допуна именици или придеву, као у примерима:

8) Кадри смо постићи врло много.

9) Имамо право то и учинити.

Инфинитив, осим тога, често врши службу субјекта, као нпр.:

10) Живети значи радити.

Инфинитив сматрамо субјектом и у реченицама типа:

11) Штетно је пушити.

иако смо свесни тога да има и другачијих гледања на његову улогу.

Поред инфинитива говорићемо још о допунским реченицама које почињу са да и што. Као заједнички назив за оба ова везника и за инфинитив преузећмо из генеративне граматике термин комплементизатор. Комплементизатор је, дакле, све што служи за увођење допунске реченице, па био то везник или друго средство за увођење зависне конструкције као што је инфинитив (тачније: инфинитивни наставак). Осим наведених српскохрватски има комплементизатор како уз глагол перцепције (нпр. Гледам Јована како игра тенис), затим комплементизатор за зависно-упитне реченице и неке друге које би све требало узети у обзир у једној комплекснијој студији ове проблематике. (У најновијим варијантама генеративне граматике, у положају комплементизатора могу се наћи и многи други синтаксички конституенти истргнути из средине реченице, међутим ту се у дискусију о ваљаности таквог описног поступка не можемо упуштати.)

Поједини комплементизатори могу али не морају ограничавати избор глаголских времена у реченицама које они уводе. Тако, на пример, комплементизатор инфинитив (инфинитивни наставак) уопште не допушта избор време́на̂, јер се, као што знамо, инфинитив не мења за прошло, садашње и будуће време. Он показује једино глаголски аспект. Са друге стране, комплементизатор што изгледа да допушта употребу свих времена, јер се каже подједнако добро: 
12) Драго ми је што сам вас видео. (перфект)

13) Драго ми је што вас видим. (презент)

14) Драго ми је што ћу вас видети. (футур)

Тачније речено, ито допушта сва времена која се срећу у независним реченицама, а то и не мора да значи баш сва времена. Ако је у реченици уведеној са што имперфективни глагол, он се заиста може појавити у било којем времену. (Ради краткоће, а и ради концентрације пажње на савремени језик какав се обично употребљава, нећу се задржавати на посебним условима за употребу имперфекта, аориста и плусквамперфекта, као и на такозваном футуру другом, који не долази у допунским реченицама. Ситуација је међутим другачија код перфективног глагола. Перфект се и даље среће у таквим зависним реченицама, а исто тако и футур:

15) Драго ми је што смо се срели.

(Слично и у независној реченици: Срели смо се.)

16) Драго ми је што ћемо се поново срести.

(Слично и у независној реченици: Срешћемо се поново.)

За разлику од перфекта и футура, услови за појаву презента перфективног глагола су врло ограничени. Најпре, он никад не значи праву садашњост. Затим, не значи ни будућност; тиме се српскохрватски језик разликује од већине других словенских језика. У независној реченици презент перфективног глагола означава радњу која се сматра типичном или карактеристичном, а обично мора бити праћен адвербијалном одредбом или другим средством које ту типичност или карактеристичност истиче. Нпр. не каже се (ван контекста) само:

17) ${ }^{\star}$ Он напише писмо.

него, рецимо:

18) Он напише писмо једанпут месечно.

19) Он напише писмо за свега пет минута.

Иста ограничења важе и за допунске реченице са што. Неће се рећи само:

20) * Драго ми је што он напише писмо.

него треба овако:

21) Драго ми је што он напише писмо једанпут месечно.

22) Драго ми је што он напише писмо за свега пет минута. 
Засад смо видели да један комплементизатор, наиме инфинитив, не допушта никакав избор глаголског времена у конструкцији коју тај комплементизатор уводи, док се други, што, по избору глаголских времена изједначује са независном реченицом. Комплементизатор да на први поглед као да не ограничава употребу време́на̂. Он се наиме среће у допунским реченицама чији глаголи могу бити у свим временима и било којег аспекта, нпр.:

23) Знам да је писао писмо / Знам да је написао писмо.

24) Желим да пише писмо / Желим да напише писмо.

25) Мислим да ће писати писмо / Мислим да ће написати писмо.

Али заправо постоје два типа употребе да, два типа који су и по избору глаголских времена која допуштају и по свом значењу толико различити да их оправдано можемо назвати два посебна комплементизатора, $\partial a_{1}$ и $\partial a_{2}$. Тек када добро сагледамо разлику између $\partial a_{1}$ и $\partial a_{2}$, моћи ћемо да схватимо у какве све односе синонимије улазе наши комплементизатори.

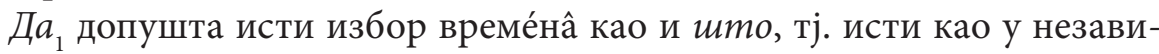
сној реченици: имперфективни глагол може бити у било ком времену, док перфективни може бити у перфекту или у футуру, а у презенту једино уз већ споменута строга ограничења. Да, се употребљава кад се садржина допунске реченице може изразити независном реченицом у индикативу. Ако кажемо, рецимо,

26) Знам да је писао писмо,

оно што знам може да се искаже и као независна реченица:

27) Писао је писмо.

Исто се односи на презент и футур имперфективног глагола у допунској реченици. У примерима:

28) Знам да пише писмо.

29) Знам да ће писати писмо.

садржина се може овако изразити:

30) Пише писмо.

31) Писаће писмо.

У случају перфективних глагола обично су могући опет само перфект и футур, нпр.:

32) Знам да је написао писмо.

33) Знам да ће написати писмо. 
Неколико случајева синтаксичке синонимије на подручју допунских реченица 533

Ту опет садржину допунских реченица можемо пренети независним реченицама:

34) Написао је писмо.

35) Написаће писмо.

Употреба презента перфективног глагола и овде је врло ограничена, а то се лако објашњава непостојањем одговарајуће независне реченице која би имала перфективни презент. Нема, дакле, допунске реченице уведене са $\partial a_{1}$ :

36) ^Знам да напише писмо.

због истог разлога због којег нема независне реченице:

37) ${ }^{*}$ Напише писмо.

О сличностима које се запажају између $\partial a_{1}$ и што говорићемо мало касније. Сада да пређемо на други комплементизатор $\partial a_{2}$. Он долази подједнако уз глаголе оба аспекта, али једино онда кад је глагол у презенту. По тој одсутности избора глаголског времена $\partial a_{2}$ је слично инфинитиву који исто тако допушта избор аспекта, али не и времена. И по значењу је налик на инфинитив, пошто оба ова српскохрватска комплементизатора изражавају радњу не као реализирану у одређеном временском термину, него као замишљену, пожељну односно непожељну и сл. Ако покушамо да парафразирамо садржину допунске реченице са $\partial a_{2}$ у облику независне реченице, глагол мора стајати у императиву, дакле, у модалном облику. Нпр.:

38) Време је да престанеш.

39) Престани!

40) Време је да предавач престане.

41) Нека предавач престане.

односно императивом. Ако пак зависна реченица стоји у првом лицу једнине:

42) Треба да почнем од почетка,

онда се мора употребити императивна конструкција у облику да + презент $\left(=\partial a_{2} ?\right)$

43) Да престанем.

(У неким се крајевима говори и: Нека почнем од почетка, али не и у књижевном језику.) 
Само још да покажемо да тип $\partial a_{2}$ стварно не допушта избор глаголских времена. Не каже се наиме овако:

44) ${ }^{\star}$ Желим да си дошао.

45) ${ }^{\star}$ Потребно је да смо радили.

46) ${ }^{\star}$ Можеш да ћеш ми помоћи.

47) *Захтевамо да нећете излазити.

Сада већ можемо да пређемо (или: можемо прећи) на разматрање синонимије и разлика у употреби појединих комплементизатора. Што и $\partial a_{1}$ су међусобно донекле синонимни јер и један и други уводе допунске реченице у којима се говори о конкретним радњама локализираним у времену. Што је специјализирано за увођење фактивних допуна, тј. оних допунских реченица за које већ унапред претпостављамо да изражавају чињеницу, па их узимамо јер желимо нешто изрећи о тој чињеници. Можемо рећи да је заслуга југословенских англиста Љиљане Бибовић из Новог Сада и Мидхата Риђановића из Сарајева што су то показали (евентуално и овако: Заслуга је англиста да су то показали). У овој реченици не тврдимо само да су то показали, него на то гледамо као на већ готов чин, чињеницу, а о тој чињеници износимо свој став, наиме да је сматрамо заслугом. Истој анализи можемо подврћи и раније наведене примере, као рецимо изразити своју радост што вас овде видим. Чињеница је да вас видим, и та чињеница ме радује.

Узгред да приметимо да се у школским уџбеницима такве фактивне допунске реченице обично називају узрочнима, с образложењем да је чињеница изражена реченицом заправо узрок осећаја казаног предикатом главне реченице. У малочас наведеном примеру узрок мојој радости био би у томе што вас видим. Такво тумачење, чини се, мање је прихватљиво у односу на предикате типа ... је нечија заслуга, јер нећемо рећи да је откриће двају англиста узрок а њихова заслуга одговарајућа последица. Пре ће бити да говорник то откриће сматра заслугом, изједначује откриће и заслугу. Лако је, уосталом, доказати да допунске реченице са што нису истог типа као и праве узрочне реченице. Наиме, може да дође заједно и једна узрочна реченица и једна фактивна допунска са што, као нпр.:

48) Драго ми је што поново видим сунце, јер га дуго није било, (..., зато што га дуго није било.)

Добићемо сасвим друго значење ако уместо допунске ставимо узрочну реченицу и обрнуто:

49) Драго ми је што сунца дуго није било, јер га поново видим. (..., зато што га поново видим.) 
Рекли смо да је што комплементизатор специјализиран за фактивне допуне. Биће тачније ако уведемо још један термин из познатог чланка брачног пара Кипарски у коме је појам фактивности први пут дефиниран. Рећи ћемо дакле да је што најкарактеристичније употребљено у фактивним емотивним допунама, онима помоћу којих изражавамо осећајни став према чињеници. У тој употреби долази и $\partial a$, тј. $\partial a_{1}$, у све већој мери барем у свакодневном, саобраћајном језику, али постоји велики распон варијације од случаја до случаја и од једног корисника језика до другога. Тако проф. Риђановић говори о синонимији што и да у многим случајевима у којима ни колегиница Бибовић ни проф. Милка Ивић, која је исто тако писала о фактивности, а и врло љубазно одговарала на моја питања, не би биле склоне да допуштају употребу $\partial a_{1}$. Наглашавам да се ради о $\partial a_{1}$, јер се уместо емотивне фактивне допуне сасвим лако може употребити $\partial a_{2}$, само што се фактивност онда губи. Ако кажемо:

50) Добро је што (или евентуално и $\partial a_{1}$ ) си стекао много пријатеља.

то значи да су конкретни пријатељи већ стечени, ради се о чињеници. Међутим, кад кажемо:

51) Добро би било да, стекнеш много пријатеља,

нема засад никаквог пријатеља, нема чињенице, него ако дође до стицања пријатеља, кажемо да ће бити добро.

Као што смо већ наговестили, има и других фактивних допуна, неемотивних. Радња се узима као чињеница па се тврди да та чињеница стоји у извесном односу према нечем другом. Ту избор што или $\partial a_{1}$ умногоме зависи од управне речи, тј. од глагола или друге речи уз коју се допунска реченица јавља. Иза знати је само $a_{1}$, никад што, иако за оно што се зна претпостављамо да је чињеница. Са друге стране, бити крив обично тражи ито: Није он крив што је онакав. Положај субјекта у главној реченици фаворизира употребу што, а исто се односи и на убацивање честица то испред зависне реченице; оба фактора видимо удружена у лепом примеру из чланка професора Риђановића:

52) То што се придјев често јавља испред именице... ствар је површинске структуре.

Занимљиво је да погледамо коју допуну тражи сама реч чињеница. Најчешће се каже чиюеница да..., али се срећу и примери са што, као у великој граматици проф. Стевановића:

53) А да је то везник [реч је управо о нашем комплементизатору umo]), јасно нам говори чињеница што је та реч овде непроменљива... (књ. I, Београд 1964, стр. 303) 
Ми смо се ту нешто дуже задржали на питању делимичне синонимије између што и да, јер је мање истражено, без обзира на то што (или на то $\partial a_{1}$, или само без обзира што) су се тиме недавно позабавили поменути лингвисти, као и проф. Ирена Грицкат у својим историјским истраживањима и колега из Норвешке проф. Свен Менесланд, који је исто тако једним чланком допринео рашчишћавању ствари. Сада бисмо се укратко осврнули на други случај синонимије, наиме на $\partial a_{2}$ и инфинитив. Српскохрватски језик, за разлику од многих других, већином не допушта употребу инфинитива тамо где имплицирани вршилац радње казане инфинитивом разликује од субјекта управног предиката. Не каже се нпр.:

54) *Хоћу Јована изаћи.

него:

55) Хоћу да Јован изађе,

тј. са $\partial a_{2}$. Тамо где се неисказани субјект инфинитива поклапа са стварним субјектом управне речи, могућ је инфинитив али могуће је и $\partial a_{2}$, опет за разлику од већине европских језика.

56) Ја ускоро морам завршити,

тј. ја морам и ја сам тај који треба да заврши, или другим речима:

57) Ја ускоро морам да завршим.

У постојећој литератури има много запажања југословенских лингвиста о разлици односно одсуству разлике између те две конструкције. Ми ћемо само напоменути да се ту може корисно применити приступ генеративне граматике Н. Чомскога, која је стекла занимљива искуства у баратању подразумеваним или неисказаним елементима у реченичној структури.

Један даљи случај синонимије на подручју комплементизатора и допунских реченица тиче се размештаја оне речи то која се јавља испред зависних реченица. У многим примерима такво то је факултативно, нпр.:

58) Весели ме то што смо се сви скупили, или

59) Весели ме што смо се сви скупили.

60) Упозорио је на то да треба изменити досадашњу праксу, или:

61) Упозорио је $\partial a_{1}$ треба изменити досадашњу праксу.

Ту су ствари још мање јасне него у претходним случајевима. У принципу бисмо могли описати дистрибуцију таквог то на два начина: (1) допуштањем двојаке рекције код глаголаิ и других управних речи (са речју 
mо односно без ње) или (2) постављањем јединствене дубинске структуре плус правило за брисање то или за његово убацивање. Код првог начина навели бисмо у лексикону да нпр. глагол упозорити тражи или на + акузатив или $\partial a_{1}+$ реченица. Реченица може стајати и уместо именичке групе у акузативу, али предлог као што је на може управљати реченицом једино посредним путем, преко речи то који се додаје и ставља у одговарајући падеж. Други начин је више у духу генеративне граматике. У лексичком опису стајало би да глагол упозорити тражи увек на + uмeничка група у акузативу. Једна од могућих реализација такве именичке групе била би и реченица праћена обликом то који стоји у потребном падежу. Према томе, то би било присутно скроз у дубинској структури допунских реченица; постојало би правило за његово брисање током прелаза из дубинске у површинску структуру. (Могли бисмо замислити и правило за увођење речи то само онда где је потребна.) Нама се други начин, тј. с присутном речју то испред сваке допунске реченице у дубинској структури, чини привлачним, јер пружа задовољавајући опис једне историјске промене која је, изгледа, сада у току. Све је наиме већи број глаголаิ и других израза иза којих, сем падежне рекције, може (на површинском нивоу) непосредно следити допунска реченица. Раније се говорило, рецимо, упозорити на нешто, па и упозорити на то да + реченица, док би била новија употреба упозорити да + реченица. Током времена, предлажемо, домет правила за брисање проширио се и на овај глагол, тако да се сад може брисати то (заједно са предлогом). У случају израза без обзира то проширење још није у потпуности извршено, тако да једни говорници прихватају склоп без обзира + реченица, док други допуштају само старију конструкцију без обзира на то + реченица. Радије ћемо дакле закључити да се једно правило постепено шири него да се безброј описа̂ лексичких јединица мењају један по један да би предвидели сваки пут исту нову могућност.

У оба могућа начина описивања ове појаве, разуме се, биће потребно утврдити семантичке, синтаксичке и стилистичке услове под којима се појављује или не појављује то, а ту, као и у другим случајевима где језички израз зависи истовремено од више чинилаца, ми, страни сербокроатисти, не можемо далеко стићи без помоћи вас којима је овај језик матерњи. ${ }^{1}$

1 Тек пошто је саопштен реферат, сазнао сам за чланак: Hilmar Walter, Конструкиије са да у савременом српскохрватском језику са конфронтативног гледишта, Научни састанак слависта у Вукове дане, Реферати и саопштења, 7/1, 1977 (објављено 1981) стр. 331-341. Извесни ставови др Валтера се лепо слажу с мојим закључцима. В. и Иван Клајн, Како се каже: речник језичких недоумица. БИГЗ, Београд, 1981, стр. 25. 
Марија Бачвански, Афективни глаголи у немачком и српскохрватском језикy. „Контрастивна језичка истраживања. Симпозијум. Нови Сад, 7. и 8. децембар 1979. Зборник радова." Нови Сад, 1980, стр. 111-117.

Љиљана Бабовић, Some Remarks on the Factive and Non-Factive Complements in English and Serbo-Croatian. „The Yugoslav Serbo-Croatian-English Contrastive Project. B. Studies 3." Загреб, 1972, стр. 37-48.

Wayles E. Browne, Релативна реченица у хрватском или српском језику у поређену с енглеском ситуацијом. Докторска дисертација, Филозофски факултет, Загреб, 1980.

Ирена Грицкат, О једном случају мешаға свеза да и што. „Наш језик”, нова серија III, 5-6. Београд, 1952, стр. 196-207.

Ирена Грицкат, Студије из историје српскохрватског језика. Народна библиотека СР Србије, Београд, 1975. (Рец.: К. Feleszko и I. Sawicka, Rocznik Slawistyczny XXXVIII, 1, 1977, стр. 124-133).

Милка Ивић, О употреби глаголских времена у зависној реченици: презент у реченици с везником да. „Зборник за филологију и лингвистику” XIII, 1. Нови Сад, 1970, стр. 43-54.

Милка Ивић, О маркированности предиката придаточных предложений по признаку мобильности. Исследования по славяннскому языкознанию. Москва, 1971, стр. 158-161.

Милка Ивић, Проблематика српскохрватског инбинитива. „Зборник за филологију и лингвистику” XV, 2, Нови Сад, 1972, стр. 115-138.

Милка Ивић, Теоријско-методолочки проблеми словенске синтаксе везани за концепт „фактивности”. „Јужнословенски филолог” XXXIII, Београд, 1977, стр. 1-16.

Paul Kiparsky и Carol Kiparsky, Fact. Progress in Linguistics, M. Bierwisch and К. Heidolph, eds. Хаг, 1970. Прештампано: Semantics: An Interdisciplinary Reader in Philosophy, Linguistics and Psychology, D. Steinberg and L. Jakobovits, eds. Cambridge, 1971, стр. 345-369.

Миодраг Ц. Лалевић, Синтакса српскохрватскога књижевног језика. Београд, 1962.

Svein Mønnesland, Semantic Factors in the Syntax of Nominal Subordinate Clauses in Serbo-Croatian. „Scando-Slavica” XVIII. Kopenhagen, 1972, стр. 145157.

Мидхат Риђановић, Употреба зависних везника што и да освијетљена појмом пресупозищије. „Књижевни језик” Х, 4. Сарајево, 1981, стр. 7-13. 
Неколико случајева синтаксичке синонимије на подручју допунских реченииа 539

Михаило Стевановић, Савремени српскохрватски језик, I. Београд 1964. II. Београд, 1969.

Wayles Browne

SOME INSTANCES OF SYNTACTIC SYNONYMY IN SENTENCE COMPLEMENTS

Summary

In Serbo-Croatian a clause introduced by a subordinating device (complementizer) can be used as a complement to a predicate or other word within a main clause. (Complement includes subjects here.) The complementizers discussed include Inf/initive/, da, što. Inf permits no choice of tense in the complement, while što allows all the same tenses as in independent indicative clauses, which means that the present of perfective verbs in quite restricted (examples 12-22). $D a$ splits into $d a_{1}$, again allowing all tenses but restricting the present of perfectives (26-37), and $d a_{2}$, allowing no choice - only the present (of perfective or imperfective verbs, 44-47). Unlike što and $d a_{1}, d a_{2}$ complements show no semantic parallelism with indicative independent clauses (38-43).

Of the two „all-tense" complementizers, što is specialized for use in factive complements, especially emotive factives, but $d a_{1}$ is encroaching on it - more for some, particularly central and western, Serbo-Croatian speakers than for others. Serbo-Croatian school grammar calls što-complements causal clauses (uzročne rečenice), but this classification is disputable (48-49). The use of the complement clause as a subject favors the choice of $r$ to, as does the appearance of to preceding and in apposition with the clause (52). The noun cinjenica "fact” takes što or (oftener) $d a_{1}$ to introduce its complement (53).

Inf and $d a_{2}$, the two complementizers not providing choice of tense, are frequently synonymous in instances where both are syntactically possible (5457). $D a_{2}$-complements can be used with many of the same main-clause predicates taking factive complements, but the factivity is then absent (50-51).

Synonymy is further observed between complement clauses proceded by appositive to (in form a neuter pronoun) and those without this pronoun (5861). Many expressions now allow both (preposition) + to $+S$ and $S$ alone as their complements; a linguistic change seems to be taking place. Rather than say that many separate lexical items are changing so as to allow an extra subcategorization possibility, we suggest that the domain of an optional to-deletion rule is expanding. 